\title{
DIALOGICZNA RELACJA LOGOPEDY I PACJENTA
}

\section{DIALOGICAL RELATIONSHIP OF THE SPEECH-LANGUAGE THERAPIST AND PATIENT}

Słowa kluczowe: logopeda, pacjent, dialogiczność, autorytet.

Keywords: speech-language therapist, patient, dialogical, authority.

\section{Wprowadzenie}

Mimo wciąż żywych dyskusji wokół współczesnej koncepcji człowieka, jego podmiotowości, wolności, godności oraz postrzegania ludzkiego życia przez kontakty z innymi, współcześnie diagnozowane jest osłabienie, wręcz rozkład więzi społecznych. U jego podstaw leży kryzys człowieka, stąd popularność haseł: „postantropocentryzm”, „posthumanizm”, wskazujących na dezaktualizację założeń klasycznej humanistyki i wyrażających świat „po człowieku”. Obserwowany kryzys komunikacji interpersonalnej wynika z rewizji pojęcia podmiotowości oraz porządku społecznego, ze świadomego zaprzestania, unikania bądź zastępowania dialogu innymi formami, destrukcyjnie wpływającymi na bezpośrednie relacje międzyludzkie. Jedną z odpowiedzi na obserwowany stan rzeczy ma być zwrot ku filozoficznym i antropologicznym nurtom XX i XXI wieku, w tym personalizmowi czy nurtowi egzystencjalno-dialogicznemu.

Życie w epoce dialogu [Szulakiewicz, 2002, s. 21] powinno być zorientowane na jego różne rodzaje: wewnętrzny, domniemany, społeczny, publiczny, dydaktyczny, wychowawczy, edukacyjny, ekumeniczny, kulturowy, dialog między umarłymi i żywymi, dialog egzystencjalny itd. [Ostrowska, 2000, s. 18]. Również w logopedii sytuacja dialogowa może zaistnieć oraz realizować się - dzięki spotkaniu człowieka z człowiekiem: logopedy i pacjenta. Szczególnie pierwszy kontakt, nawet jeszcze przed rozpoczęciem procesu diagnozy, wpływa na powstanie więzi, obdarzenie zaufaniem i szacunkiem, na pozytywną motywację do podejmowanych działań. W toku terapii logopedycznej nacisk jest położony na wspólne osiąganie określonego, optymalnego dla pacjenta celu, którym może być wygaszanie, ograniczanie czy wręcz eliminowanie problemów związanych z zaburzeniem mowy. Ponieważ zachowania językowe uwypuklają zarówno symptomy dysfunkcji, jak też pozytywne stro-

* Wydział Filologiczny, Katedra Dialektologii Polskiej i Logopedii, ul. Pomorska 171/173, 90-236 Łódź. 
ny pacjenta, na których buduje się plan i program terapii, w wielu wypadkach zainicjowanie spotkań z logopedą, ich częstotliwość, intensywność oraz jakość, stanowi warunek sine qua non sukcesu. Logopeda ma świadomość, że poszanowanie godności pacjenta i własnej wyznacza konieczność zdobycia doświadczenia, które umożliwi stworzenie przyjaznej atmosfery, pozwoli w jak najlepszy sposób zorganizować kolejne spotkania, a formę czy rytm pracy dopasować indywidualnie do pacjenta.

Logopeda, jako organizator spotkań, przyjmuje różne postawy w kontakcie z pacjentem, co wynika między innymi z zaufania do swojej wiedzy i umiejętności, przeświadczenia o znawstwie przedmiotu, zaangażowania w proces diagnostyczno-terapeutyczny, charakteru, otwartości na drugiego człowieka, umiejętności przyjmowania krytyki czy niepowodzeń, wymagań stawianych przez rodzica/opiekuna bądź placówkę, temperamentu itp. Zakłada się, iż relacja pacjent-logopeda jest relacją binarną: indywidualności - pacjenta (przypadku) z zasadą - logopedą (szerszą świadomością budowaną na podstawie wiedzy oraz refleksji opartej na terapii prowadzonej z wieloma pacjentami). Dlatego też terapeuta jest postrzegany, a także oceniany, głównie przez pryzmat kompetencji i umiejętności, które są w znacznym stopniu mierzalne, możliwe do zweryfikowania, pozwalają osiągnąć cel terapeutyczny czy określić skuteczność prowadzonych działań. Rzadziej podkreśla się, że podczas spotkania, czyli obecności człowieka obok lub naprzeciw drugiego, ze względu na określone zachowania (też językowe), następuje proces krystalizacji podmiotowości obu uczestników dialogu, kształtuje się tożsamość i osobowość każdego z nich.

\section{Dialog-rozmowa, dialog twarzą w twarz}

Logopeda i pacjent to dwie osoby, które spotykają się w chwili rozpoczęcia procedury logopedycznej. Wówczas ma miejsce dialog, rozumiany jako rozmowa minimum dwóch osób, wymiana komunikatów, myśli, emocji, uzgodnienie stanowisk oraz zbliżenie punktów widzenia, czyli proces interakcyjny w celu porozumienia i zrozumienia się [Encyklopedia językoznawstwa ogólnego, 1999, s. 120, sv. dialog; Śnieżyński, 1997, s. 139]. Dialog to najważniejszy sposób interakcji międzyludzkiej, którego składową jest również dialog twarza $w$ twarz, nazywany prototypowym aktem mowy (prototypical speech act, Levinson) albo fundamentem językowego użycia (fundamental site of language use, Clark, Wilkes-Gibbs) [Załazińska, 2006, s. 12]. W takim znaczeniu rozmowę można postrzegać jako dialogiczną formę użycia języka (z gr. dialogein - 'rozmawiać'), podstawową dla komunikacji międzyludzkiej [Załazińska, 2006, s. 14]. Używanie języka oraz umiejętność mówienia warunkują kształt i jakość życia człowieka, jak również jego relacji z innymi.

Trudności w analizowaniu dialogu wynikają z jego dynamiki, ulotności i eliptyczności, a niekiedy nawet symultanicznie wygłaszanych monologów. Jako „żywa mowa" dopuszcza pomyłki czy niepoprawne użycie kategorii gramatycznych, zaburzenia suprasegmentalne, znaczną ekspresję ciała, w tym nadmiar gestów i mimiki twarzy, co może być efektem zaangażowania rozmówcy oraz emocjonalności wypowiedzi. Jednak rozumienie twarzy jako konkretnego bytu, „mówiącej” części człowieka, którą można ogarnąć wzrokiem, w pewnej mierze prowadzi do uprzed- 
miotowienia. W sensie filozoficzno-metafizycznym, jaki nadaje dialogika, w dialogu buduje się relacja pomiędzy uczestnikami spotkania, relacja, dzięki której przekracza się ontologię: „Tylko relacja z innym człowiekiem wprowadza wymiar transcendencji i prowadzi do całkowicie innego stosunku niż doświadczenie w zmysłowym sensie terminu, względne i egoistyczne" [Lévinas, 2002, s. 226].

Filozofia spotkania, zwana inaczej filozofią dialogu, ma swoje źródła w buncie przeciwko reifikacji człowieka, przeciw nowożytnemu racjonalizmowi i idealizmowi, zwraca uwagę na etyczny wymiar relacji międzyludzkich [Kłoczkowski, 2005; Zielewska, 2002]. Według Martina Bubera jest to partnerska, wzajemna relacja Ja-Ty, Emmanuel Lévinas podkreśla zaś jej niesymetryczność, odrębność podmiotów Ja-Inny [Załazińska, 2006, s. 27]. M. Buber zwraca uwagę na (nie)trwałość oraz funkcjonowanie relacji międzyludzkich, E. Lévinasa zajmuje zaś ich geneza i uwarunkowania. Obaj filozofowie podkreślają, że jednostkowa podmiotowość człowieka może się realizować tylko w interakcji z Ty/Innym.

\section{Relacja w dialogu}

Dla M. Bubera relacja binarna Ja-Ty to wybór samego człowieka, który w chwili spotkania dookreśla siebie, szanując podmiotowość Ty, traktując każdego uczestnika spotkania jako samodzielną jednostkę, którą jest naprawdę, nie zaś projekcję pewnego wyobrażenia tworzoną przez Ja. Prawdziwy dialog wymaga akceptacji odmienności, zakłada też możliwość odpowiadania [Rosner, 2011, s. 19]. Dla M. Bubera konkretna rozmowa toczy się w relacji równowagi oraz wzajemności - każdy z uczestników mówi (nadaje, przekazuje) i słucha (odbiera) [Buczyńska-Garewicz, 1980, s. 882]. W odróżnieniu od relacji wzajemności Ja-Ty, która jest „rzeczywistym wyjściem ku drugiemu i byciem z nim” [Buber, 1992, s. 228], zależność Ja-To/Ono prowadzi do uprzedmiotowienia partnera spotkania. Zmiana relacji na nierównorzędną jest efektem posiadania (postrzegam, przedstawiam sobie, myślę, odczuwam) [Baran, 1991, s. 15] poznawanego przedmiotu, utrzymania dystansu.

W klasycznym ujęciu filozofii dialogu M. Bubera otwarcie na $T y$, partnerstwo w relacji równorzędnej czy współdziałanie podmiotów może prowadzić do wzajemnego rozumienia oraz poczucia bliskości, które realizuje się przed- i pozawerbalnie, ale też w rozmowie i dzięki niej. Otwartość, wzajemność oraz akceptacja drugiej osoby warunkują prawdziwą rozmowę, prawdziwą komunikację, która nie polega tylko na wymianie informacji za pomocą języka. Właśnie zastępowanie relacji dialogowej $J a-T y$ monologiem zorientowanym na przedmiot wypowiedzi: Ja-To/Ono, odzwierciedla kryzys człowieka.

Relacja Ja-Ty M. Bubera, jako odpowiedź na kryzys kultury europejskiej, rodziny i relacji międzyludzkich, wskazuje, że „istoty człowieka nie należy szukać w odłączonych indywiduach, ponieważ naszą istotą jest łączność osoby ludzkiej z pokoleniem, do którego należy, i ze społeczeństwem, w którym żyje. Jeśli więc chcemy poznać istotę człowieka, musimy poznać istotę tej więzi” [Buber, 1993, s. 70]. Pierwotne jest wchodzenie w relację z Ty i dążenie do niej, nie zaś zdystansowany ogląd, analiza, kategoryzowanie świata czy redukcjonizm charakterystyczny dla nauk przyrodni- 
czych. Doświadczenie Ty jest doświadczeniem całości osoby, czyli jej jedności, nie zaś indywiduum złożonego $\mathrm{z}$ wielu różnych części. Jeśli zaistnienie relacji oraz wytworzenie więzi prowadzi do wyłączności, „wówczas można działać, pomagać, uzdrawiać, wychowywać, wspierać, wyzwalać” [Buber, 1991, s. 44].

Również relacja Ja z Innym E. Lévinasa zachodzi podczas spotkania twarza $w$ twarz, podkreślającą zredukowanie dystansu i skupienie uwagi na drugim. Twarz naprzeciwko wyraża odmienność, osobę, którą można poznawać, choć do ostatecznego i pełnego poznania nie dojdzie ze względu na inność, odmienność podmiotu. Ja doświadcza bycia z drugim twarza $w$ twarz, która mówi. Dzięki usytuowaniu naprzeciw pojawiają się zarówno możliwość i potrzeba, jak też prowokacja, wyzwanie, zobowiązanie do podjęcia dialogu. E. Lévinas również nie pojmuje twarzy Innego jako konkretnego bytu, lecz początek języka i nadawanego znaczenia w doświadczaniu drugiego. Czynność mówienia poświadcza obecność Innego, który, zwracając się twarzą do $J a$, spełnia warunek do zaistnienia komunikacji, a podczas mówienia uobecnia się w języku, przez język czy dzięki językowi. Wysłuchane słowo oraz mówienie dają możliwość bycia-w-świecie [Kłoczowski, 2005, s. 79], wykraczania poza siebie. Wypowiadane frazy, czyli to, co powiedziane, są wtórne wobec samego mówienia.

W odróżnieniu od M. Bubera, E. Lévinas wskazuje, że relacji dialogicznej nie cechuje równorzędność czy wzajemność [Lévinas, 2002, s. 29], pojawia się raczej asymetria i odpowiedzialność za Innego, którą rozpatruje się w kategoriach obowiązku [Kozak, 2011, s. 37], gotowości do rezygnacji z siebie, poświęcenia dla Innego. Możliwe jest spotkanie, ale nie podporządkowanie Innego sobie. W kontekście współczesnej kultury będzie to zatem spotkanie z człowiekiem zagubionym, potrzebującym wejść w relację, mimo różnic i dystansu.

\section{Autorytet w dialogicznej relacji logopeda-pacjent}

W logopedii filozofia dialogu znajduje swoje odzwierciedlenie w relacji opartej na wzajemnym szacunku, godności oraz akceptacji jedyności, czyli wyjątkowości podmiotów. Sprzyjają temu zarówno inter- i transakcyjność, jak też transgresyjność. Podczas spotkania zarówno pacjent, jak i logopeda oddziałują na siebie wzajemne, co więcej - poza tym, że każdy wchodzi w akcję z samym sobą, powinien mieć tė̇ zdolność przekraczania siebie, wychodzenia do drugiego z poszanowaniem granic jego autonomii oraz wolności. Relację logopedy i pacjenta cechuje jednak asymetryczność.

W tym układzie autorytet epistemiczny [Bocheński, 1993, s. 242], oparty na kompetencjach logopedy, trwa do momentu zakończenia terapii. Odpowiedzialność za pacjenta to odpowiedzialność za organizację spotkań, wybór, ukierunkowanie i - w pewnej mierze - przebieg aktywności. Za Lévinasem można uznać, że odpowiedzialność uwzględnia i każe przyjąć dysproporcje, jednak w gabinecie nie można zapominać o współodpowiedzialności za ostateczny efekt terapii, skoro działania zakładają kreatywność, jak również znaczną samodzielność pacjenta, oczywiście w miarę jego możliwości psychofizycznych. Logopeda pomaga i zachęca, ale tė̇ 
wspiera, dąży do zrozumienia sytuacji problemowych. Dzięki temu może dojść zarówno do odkrycia przez pacjenta trafnego rozwiązania czy rozpoznania własnych możliwości, jak również dostrzeżenia przez logopedę niezaobserwowanych i niesklasyfikowanych wcześniej kompetencji bądź umiejętności pacjenta. Takie spotkanie może prowadzić do weryfikacji programu terapii logopedycznej, co będzie efektem wzajemnego wpływu obu podmiotów ${ }^{1}$ logopedycznych.

Uznanie autorytetu epistemicznego wyraża się w zaufaniu pacjenta do logopedy jako znawcy przedmiotu, specjalisty w swojej dziedzinie. Ponieważ terapia nie jest tożsama z sytuacją lekcyjną (zależność uczeń-nauczyciel) bądź zawodową (zależność podwładny-przełożony), logopeda z reguły nie pełni stereotypowo rozumianej funkcji kierowniczej, która kojarzy się z oceną bądź sankcjami. Jednak po części posiada autorytet deontyczny solidarności [Bocheński, 1993, s. 293], gdyż może przyjmować kierowniczą rolę ze względu na pacjenta i cel nadrzędny - skuteczność procesu diagnostyczno-terapeutycznego. Logopeda organizuje i czuwa nad przebiegiem terapii, weryfikuje poziom wykonania zadań, ale skupia się głównie na pozytywnym motywowaniu do dalszej pracy. Co istotne, podczas terapii logopedycznej może nastąpić zamiana ról. Kiedy logopeda przekazuje część władzy pacjentowi, następuje delegacja autorytetu deontycznego. Z reguły, i w miarę możliwości, pacjent staje się współodpowiedzialnym podmiotem terapii, między innymi dzięki świadomości i akceptacji celów oraz planu działania, wzmocnieniu poczucia bezpieczeństwa, szacunku i otwartości. Następuje wówczas redukcja dystansu, zwiększa się aktywność podczas terapii oraz zaangażowanie w ćwiczenia domowe.

Personalistyczny charakter relacji logopedy i pacjenta wymaga spojrzenia na oboje jako byty osobowe równorzędne, choć wiedza i umiejętności logopedy (byt w akcie) oraz cele i możliwości, projektowana korekta zaburzeń mowy u pacjenta (byt w możności) wyznaczają logopedzie rolę przewodnika. Asymetria nie musi prowadzić do uprzedmiotowienia jednej strony dialogu. Dzięki autorytetowi osobistemu, inaczej moralnemu, logopeda może osiągać dobre wyniki, kiedy dba o partnerską relację, w której następuje otwarcie na drugiego człowieka. Odczuwane są wtedy szczerość intencji oraz poczucie bezpieczeństwa. Pewne podporządkowanie się autorytetowi - logopedzie - nie oznacza bezrefleksyjnego i bezwzględnego posłuszeństwa, ale chętne korzystanie z własnej wolności, niezależności oraz kreatywności pod czujnym okiem przewodnika profesjonalisty, który, wrażliwy na potrzeby innych, aktywizuje pacjenta i wyzwala jego możliwości.

Dzięki autorytetowi osobistemu logopeda nierzadko stanowi wzorzec, który pacjent - świadomie bądź nie - w pewnym stopniu naśladuje i powiela, co może skutkować tożsamością zapożyczoną od terapeuty. Bycie autorytetem, wzorem osobowym, dla niejednego logopedy oznacza konieczność nieustannego samodoskonalenia, ciągłego dopełniania wiedzy, pracy nad sobą, również zmagania się z własnym napięciem emocjonalnym i niwelowaniem oporu przed większym otwarciem na pacjenta i zaangażowaniem w terapię. Na przeszkodzie niejednokrotnie staje poczucie bez-

1 Mimo iż J.M. Bocheński używa określenia „przedmiot autorytetu”, czyli ten, „dla którego podmiot autorytetu jest autorytetem" [Bocheński, 1993, s. 202], zgodnie z założeniami niniejszego opracowania pacjent traktowany jest jako podmiot w relacji z autorytetem - logopedą. 
silności czy frustracja, gdy ambitne cele nie zawsze są realizowane w rzeczywistości bądź terapia nie przynosi zakładanych efektów w przewidywanym czasie. Według niektórych dystans emocjonalny oraz skupienie uwagi na wadzie/zaburzeniu mowy gwarantują większą skuteczność prowadzonej terapii.

\section{Dialog logopedy i pacjenta}

Dialogiczna relacja logopedy i pacjenta nie jest nastawiona na przedmiot terapii, czyli zaburzenie mowy (To), lecz podmiot - pacjenta z zaburzeniem mowy (Ty/Inny). Jedyność i samookreślenie, wyjątkowość nieredukowalna do powszechnej czy obcej formy pozwala wchodzić w interakcje Ja-Ty/Inny. Rola logopedy jako uczestnika spotkania Ja-Ty/Inny oraz przewodnika po świecie mowy może mieć istotne znaczenie w postrzeganiu wady/zaburzenia przez pacjenta, w kształtowaniu ponadindywidualnej oraz jednostkowej tożsamości - tożsamości podmiotowej, która przeciwstawiana jest przyjmowanej oraz wytwarzanej formie, na przykład sposobowi myślenia, mówienia, działania czy bycia.

Dialogiczna relacja Ja-Ty w czasie spotkania logopedy i pacjenta jest skuteczniejszą formą komunikacji niż wyrażanie poglądów i jednostkowych doświadczeń w monologu, monologu imitującym dialog bądź dialogu technicznym [Buber, 1992, s. 226]. Cerebracja, czyli doświadczanie To, myślenie o otaczającej rzeczywistości, dokonuje się zawsze wewnątrz człowieka. Relacja zachodzi w interakcji, od chwili rozpoczęcia manifestowania intencji i celu, nie zaś dopiero od werbalnego przekazywania treści komunikatu.

W trakcie diagnozy i terapii logopedycznej organizatorem spotkania i inicjatorem dialogu częściej jest logopeda. Choć czasami nabieranie zaufania do logopedy zajmuje kilka wizyt, nie są to chwile stracone. W przypadku najmłodszych stopniowe oswajanie się z miejscem i dorosłym mogą wspierać rodzice/opiekunowie, którzy z czasem powinni ograniczyć swoją rolę do obserwowania terapii, a ostatecznie przestać uczestniczyć w spotkaniach logopedy i pacjenta. Założenie takie wynika ze specyfiki spotkania. Jeśli pacjent będzie bytem relacyjnym - w odniesieniu do - i w zależności od rodzica, może nastąpić zatracenie człowieka-osoby. Podobnie deformacja relacji interpersonalnej następuje wówczas, gdy terapii narzucone są aprioryczne, ideologiczne cele instytucjonalne bądź instrumentalne, które logopeda próbuje wcielać w życie bez względu na pacjenta.

Jeśli spotkania z pacjentem sprowadzają się do funkcji informacyjnej, dotyczą jedynie objaśnienia czy instruktażu niezbędnego dla skuteczności terapii danego zaburzenia mowy, mechanicznych ćwiczeń - odnoszą się do sfery Ja-To. Cechują je głównie: ekonomia czasu, skuteczność i nastawienie na wymierny efekt. Poznawcza relacja z otoczeniem nie wyczerpuje sytuacji dialogu, którego wiedzo- i socjotwórczy charakter zakłada poszerzanie słownictwa czynnego i biernego, wzbogacenie ogólnej wiedzy i stymulowanie rozwoju pacjenta, ale również poszerzenie horyzontów logopedy, zgodnie z łacińską maksymą: Cum doceo, disco. Dzięki empatii, elastyczności, przekraczaniu własnych horyzontów poznawczych oraz schematów działania, a także kreatywnemu, a zarazem odpowiedzialnemu podejściu, terapeuta może wyzwolić w pacjencie potrzebę kontaktu, dialogu twarza w twarz. 
Prawdziwy dialog rozpoczyna się w momencie przejścia od mechanicznego tzw. tropienia z pamięci wiedzy znanej czy prostego wnioskowania do rozmowy wyznaczanej między innymi przez kroki inicjujące, reagujące oraz reaktywujące [Żydek-Bednarczuk, 1994, s. 52-96], czyli przez: pytania zadawane sobie oraz drugiemu, zachęty, aktywne słuchanie, komentowanie wypowiedzi, modyfikację tematu w obopólnym porozumieniu oraz autentyczne i niekłamane zainteresowanie wypowiedziami drugiego. Cyrkularny charakter dialogu w logopedii, czyli gotowość do zamiany ról nadawcy i odbiorcy, zakłada konfrontację własnych opinii z odbiorcą, wymuszającą otwieranie się na drugiego, aktywne słuchanie, przekraczanie swoich granic, dopełnianie tego, co znane, nowymi treściami.

Dialog dopuszcza niewiedzę, poszukiwanie, wątpliwości, odmienne poglądy, autonomię, wzajemne przejmowanie respektów poznawczych, swobodę w formowaniu oraz wygłaszaniu poglądów [Palka, 2003, s. 483]. Dialog twarzą w twarz wymaga zainicjowania i podtrzymywania kontaktu (funkcja fatyczna), cechuje go względnie swobodna, gdyż determinowana kulturowo ekspresja werbalna, a także pozawerbalna, podkreślająca bądź nadająca znaczenie współpracy podczas interakcji [Załazińska, 2006, s. 14]. Wówczas odpowiedzi nabierają najbardziej charakterystycznych cech dialogu: są improwizowane, precyzyjne i natychmiastowe, charakterystyczne dla słuchania dialogicznego. Jest ono pewnym ideałem w relacji dialogicznej, lecz podczas realnej rozmowy nierzadko zastępują je mniej doskonałe postawy, jak na przykład: sondowanie interlokutora, forsowanie własnych opinii, brak zrozumienia intencji komunikacyjnych nadawcy [Załazińska, 2006, s. 61].

Dla pacjenta prawdziwy dialog może być końcem alienacji i izolacji, jednocześnie katalizatorem aktywnego działania i organizacji własnego życia. Jest to przejście od traktowania języka jako narzędzia komunikacji do (od)budowania świata pacjenta dzięki językowi i w języku, tłumaczenia rzeczywistości, budowania relacji społecznych oraz dookreślania własnego „ja” [Pluta-Wojciechowska, 2013, s. 10]. Wiąże się to z poszanowaniem autonomii obu stron dialogu, a wyraża w akceptowaniu inności.

\section{Zakończenie}

Zawód logopedy opiera się na akceptacji podmiotowości uczestników procesu diagnostyczno-terapeutycznego [Błachnio, 2001, s. 18; Jeziorska-Bednarz, 2009, s. 7], jest i nauką, i sztuką, i służbą [Cieszyńska, 2005, s. 112]. Wymaga zawieszenia negatywnych emocji, wyzwolenia w sobie życzliwości oraz zorientowania na dobro drugiego. Dlatego w relacji logopedy i pacjenta trzeba pamiętać, że jest to głównie spotkanie człowieka z człowiekiem, nie zaś tylko specjalisty z przypadkiem.

W dialogicznej relacji z pacjentem logopeda jest przewodnikiem, profesjonalistą, który sytuuje się na pozycji znawcy, partnera Ty/Innego w toku diagnozy i terapii. Dzięki interakcji opartej na mowie, ale również reagowaniu na sygnały, pozostawaniu w kontakcie wzrokowym, dostosowywaniu się do możliwości pacjenta czy podejmowaniu aktywności twarza w twarz, może następować rozpoznawanie, lepsze rozumienie i akceptacja drugiego, czyli powstanie więzi. Efektem terapii opartej na 
dialogu zawsze będzie jedyność, nigdy jedność rozumiana jako synteza, upodobnienie dwóch osób. I pacjent, i logopeda pozostają sobą.

Ponieważ znaczną część pacjentów logopedycznych stanowią dzieci bądź dorośli wymagający opieki, często następuje deformacja relacji binarnej, która przechodzi w układ trinarny. Istnieje wówczas konieczność dookreślenia roli trzeciego uczestnika spotkań (rodzica, dziadka, współmałżonka, pielęgniarki, opiekuna i innych), uświadomienia mu współodpowiedzialności za przebieg terapii i komunikację pacjenta, ale również jakość jego życia (Quality of Life), którego nie może definiować czy determinować wada/zaburzenie mowy.

\section{Bibliografia}

Baran Bogdan, 1991, Przedmowa, w: tenże (red.), Filozofia dialogu, Kraków, s. 7-35.

Błachnio Krystyna, 2001, Logopedia jako nauka i służba społeczna, w: taż, Vademecum logopedyczne, Poznań, s. 19-97.

Bocheński Józef Maria, 1993, Co to jest autorytet?, w: tenże, Logika i filozofia. Wybór pism, tłum. i opr. Jan Parys, Warszawa, s. 187-324.

Buber Martin, 1991, O Ja i Ty, tłum. Jan Doktór, w: Bogdan Baran (red.), Filozofia dialogu, Kraków, s. 37-56.

Buber Martin, 1992, Ja i Ty. Wybór pism filozoficznych, tłum. Jan Doktór, Warszawa. Buber Martin, 1993, Problem człowieka, tłum. Robert Reszke, Warszawa.

Buczyńska-Garewicz Hanna, 1980, Martin Buber i dylematy subiektywności, „Znak”, 7, s. $875-889$.

Cieszyńska Jagoda, 2005, Od kompetencji niewerbalnej do językowych realizacji intencji u małych dzieci niesłyszacych, „Logopedia”, 34, s. 97-114.

Encyklopedia językoznawstwa ogólnego, 1999, Wrocław.

Grabias Stanisław, 1994, Język w zachowaniach społecznych, Lublin.

Jeziorska-Bednarz Ewa, 2009, Logopedia XXI wieku. Zmieniające się oczekiwania wobec terapeuty zaburzeń mowy, „Forum Logopedyczne”, 16, s. 5-7.

Kłoczowski Jan Andrzej, 2005, Filozofia dialogu, Poznań.

Kozak Magdalena, 2011, Dlaczego Lévinas nie jest filozofem dialogu?, w: Sabina Kruszyńska, Krystyna Bembennek, Iwona Krupiecka (red.), Dialog. Idea i doświadczenie, Gdańsk, s. 33-43.

Lévinas Emmanuel, 2002, Całość i nieskończoność. Esej o zewnętrzności, tłum. Małgorzata Kowalska, wstęp Barbara Skarga, Warszawa.

Nowacki Tadeusz, 1999, Zawodoznawstwo, Radom.

Ostrowska Urszula, 2000, Dialog w pedagogicznym badaniu jakościowym, Kraków.

Palka Stanisław, 2003, Dialog w dydaktyce ogólnej i praktyce kształcenia, w: Anna Karpińska (red.), Teoria i praktyka kształcenia $w$ dialogu i perspektywie, Białystok, s. 481-487.

Pluta-Wojciechowska Danuta, 2013, Dokąd zmierza logopedia?, „Forum Logopedyczne”, 21, s. 9-21.

Rosner Katarzyna, 2011, Dialog jako temat filozofii wspótczesnej: Buber, Gadamer, Habermas, w: Sabina Kruszyńska, Krystyna Bembennek, Iwona Krupiecka (red.), Dialog. Idea i doświadczenie, Gdańsk, s. 15-32. 
Szulakiewicz Marek, 2002, Filozofia jako dialog. Nadzieje i złudzenia nowego myślenia, w: Józef Baniak (red.), Człowiek z przełomu wieków w refleksji filozofii dialogu, Poznań, s. 21-38.

Śnieżyński Marian, 1997, Zarys dydaktyki dialogu, Kraków.

Załazińska Aneta, 2006, Niewerbalna struktura dialogu: w poszukiwaniu polskich wzorców narracyjnych i interakcyjnych zachowań komunikacyjnych, Kraków.

Zielewska Beata, 2002, Dialog we współczesnej edukacji filozoficznej, Olsztyn.

Żydek-Bednarczuk Urszula, 1994, Struktura tekstu rozmowy potocznej, Katowice.

Summary

This text shows that in the era of dialogue, in which - paradoxically - crisis of interpersonal communication is diagnosed, meetings between a speech-language therapist and the patient should be based on the principles of face-to-face dialogue, on a real relationship of dialogic participants, despite the asymmetry resulting from the tasks of both sides of speech therapy. Position of the therapist and his authority can't explain the ascendency over the patient. According to the assumption of dialogic, dialogue can't be reduced only to the conversation as alternating exchange of messages, but it is interpersonal relationship, which is the result of openness, genuine interest in other person. Therefore true dialogue should create social relationships. 